\title{
Trūkumi Ārstniecības riska fonda regulējumā
}

\author{
Aldis Liepiňš \\ Rīgas Stradiña universitāte, Sabiedrības veselības \\ un epidemiologijas katedra, Latvija \\ Aldis.Liepins@rsu.lv \\ Jānis Vètra \\ Rìgas Stradiña universitāte, Anatomijas \\ un antropologíijas institūts, Latvija \\ Osvalds Joksts \\ Rigas Stradina universitāte, \\ Juridiskā fakultāte, Latvija
}

\section{Kopsavilkums}

Eiropas Parlamenta un Padomes 2011. gada 9. marta direktīvā 2011/24/ES par pacientu tiesību piemērošanu pārrobežu veselības aprūpē noteikts, ka dalībvalstij ir pienākums nodrošināt pacientiem pieejamas un pārredzamas sūdzību procedūras un mehānismus, kas dod viṇiem iespēju lūgt aizsardzības līdzekḷus saskañā ar dalībvalsts tiesību aktiem, ja sniegtās veselības aprūpes dēl ir nodarìts kaitējums. Tādēl 2013. gada 25. oktobrī Latvijā pēc Zviedrijas un Dānijas parauga tika ieviests Ārstniecības riska fonda koncepts. Ar 2013. gada 17. oktobra likumu tika grozīts Pacientu tiesību likums, kurā vispārīgi noteikti pacientu tiesību aizsardzības līdzekḷa, proti, Ārstniecības riska fonda principi. Savukārt fonda darbību reglamentē Ministru kabineta 2013. gada 5. novembra noteikumi "Ārstniecības riska fonda darbības noteikumi". Šis regulējums nodrošina pacientu tiesības uz atlīdzību par pacienta dzīvībai vai veselībai nodarìto kaitējumu.

Ārstniecības riska fonda darbību nodrošina divas iestādes, kas atrodas Veselïbas ministrijas tiešā padotībā, - Nacionālais veselības dienests un Veselības inspekcija.

Pētījumā tiek analizēta Ārstniecības riska fonda darbības procesuālā kārtība, noteikta cēlon, sakarība starp kaitējumu personai un sniegto veselības aprūpi, kā arī 
skatīts kompensācijas apmēra noteikšanas jautājums. Pētījumā tika identificētas vairākas problēmas, izdarīti secinājumi par Ārstniecības riska fonda koncepta ieviešanas atbilstỉbu Eiropas Parlamenta un Padomes 2011. gada 9. marta direktīvas 2011/24/ES par pacientu tiesību piemērošanu pārrobežu veselības aprūpē prasībām (vai normām), secinot, ka direktīvas prasības nav implementētas pilnīgi. Tika secināts, ka Ārstniecības riska fonda darbības noteikumi neatbilst Pacientu tiesību likuma regulējumam un procesuālajiem principiem, kas nodrošina personu tiesības uz taisnīgu tiesu, kā arī tika sniegti priekšlikumi, lai uzlabotu Ārstniecības riska fonda regulējumu.

Atslēgvārdi: pacientu tiesības uz atlīdzību, Ārstniecības riska fonds.

\section{levads}

Eiropas Komisija secinājusi, ka 8-12 \% Eiropas Savienības slimnīcās uzṇemto pacientu cieš ar veselības aprūpi saistītos negadījumos:

- no infekcijām, kas saistītas ar veselības aprūpi (aptuveni $25 \%$ no visiem nevēlamajiem gadijumiem);

- no ārstēšanas kḷūdām;

- no ḳirurgiskām klūiām;

- no medicīnas iekārtu vai instrumentu darbības traucējumiem un kḷūmēm;

- no diagnostikas kḷūdām;

- pēc medicīniskajām pārbaudēm nesniegtas palīdzības dēl [8].

Latvijas Republikas Satversmes 111. pantā noteikts, ka "valsts aizsargā cilvēku veselību [..]" [15].

Līguma par Eiropas Savienības darbïbu 168. panta 2. punktā noteikts, ka Savienības rīcība papildina dalībvalstu politiku un ir vērsta uz to, lai uzlabotu sabiedrības veselību, veiktu slimību profilaksi un novērstu draudus cilvēku fiziskajai un garīgajai veselībai. Šāda rīcība paredzēta arī cīnai pret slimībām, kuras visvairāk apdraud veselību, veicinot pètījumus par to cēloṇiem, izplatīšanos un profilaksi, kā arī gādājot par sabiedrības informēšanu un izglītošanu par veselības jautājumiem un nopietni pārraugot pārrobežu veselības apdraudējumus, laikus brīdinot par tiem un šos draudus apkarojot [18].

Uzlabojot iekšèjā tirgus darbību un preču, personu un pakalpojumu brīvu apriti, Eiropas Parlaments un Padome 2011. gada 9. martā pien̦ēma direktīvu 2011/24/ES par pacientu tiesību piemērošanu pārrobežu veselības aprūpē [10]. Direktīvā 2011/24/ES noteikts dalībvalsts pienākums nodrošināt pacientiem pieejamas un pārredzamas sūdzību procedūras un mehānismus, kas dod viniem iespēju lūgt aizsardzības līdzekḷus atbilstīgi dalībvalsts tiesību aktiem, ja veselības aprūpes dēl ir nodarīts kaitējums. Tādēl 2013. gada 25. oktobrī Latvijā pēc Zviedrijas un Dānijas parauga tika ieviests Ārstniecības riska fonda koncepts.

Pētỉjumā tiek analizēta Ārstniecības riska fonda procesuālā kārtība, cēloṇsakarības starp kaitējumu personai un sniegto veselības aprūpi noteikšanas problemātika 
un kompensācijas apmēra noteikšanas jautājums. Pētījumā tiek izdarīti secinājumi par Ārstniecības riska fonda koncepta ieviešanas atbilstību direktīvai 2011/24/ES, Pacientu tiesību likumam un vispārējiem procesuālajiem principiem, kā arī tiek sniegti priekšlikumi Ārstniecības riska fonda darbības uzlabošanai.

\section{Pacientu tiesības uz atlīdzību}

Ārstniecības personu atbildība par pacienta veselībai nodarīto kaitējumu un pacienta tiesības uz atlīdzību vispārīgi noteiktas Ārstniecības likumā [4], likumā "Par prakses ārstiem" [17], Pacientu tiesību likumā [24] un Civillikuma normās par līguma sekām un atbildības pienākumu (1587.-1634. p.), par neaț̣autu darbỉbu un vainas pakāpēm (1635.-1650. p.), par miesas bojājumiem (2347.-2351. p.) [7]. Kopš Pacientu tiesību likuma spēkā stāšanās pacientu tiesības uz atlīdzību expressis verbis ir noteiktas Pacientu tiesību likuma 16. pantā. Pacientu tiesības saņemt kompensāciju ir noteiktas arī Eiropas Pacientu tiesību hartā [9], kas gan nav normatīvs akts. Ar 2013. gada 17. oktobra likumu "Grozỉjumi Pacientu tiesību likumā” tika ieviests vēl viens pacientu tiesību aizsardzības līdzeklis, proti, Ārstniecības riska fonds, kura darbību reglamentē Ministru kabineta 2013. gada 5. novembra noteikumi "Ārstniecības riska fonda darbības noteikumi" [5] (turpmāk - arī ĀRF noteikumi). Šajos noteikumos tika veikti grozijumi ar Ministru kabineta 2016. gada 19. janvāra noteikumiem Nr. 44 "Grozijjumi Ministru kabineta 2013. gada 5. novembra noteikumos Nr. 1268 "Ārstniecības riska fonda darbības noteikumi”" [12].

Pacientam ir tiesības uz atlīdzību par:

1) veselībai vai dzīvībai nodarīto kaitējumu (arī morālo);

2) ārstniecības izdevumiem.

Atlīdzību no Ārstniecības riska fonda izmaksā kopš 2014. gada 1. maija par kaitējumu, kas nodarīts pacientam pēc 2013. gada 25. oktobra.

Tādējādi kopš 2013. gada 25. oktobra ir mainïjusies pacientu tiesību uz atlīdzību procesuālā paradigma. Līdz 2013. gada 25. oktobrim persona, kurai ārstniecības procesā nodarīts kaitējums, t. i., pacients, veselībai nodarītā kaitējuma kompensāciju prasīja no ārstniecỉbas iestādes vai ārstniecības personas. Strīdu gadỉjumā šo pacienta prasību izskatīja tiesa civilprocesuālā kārtībā. Arī šobrīd tiesas prasības kārtībā izskata lietas par pacienta dzīvībai vai veselībai nodarītā kaitējuma, kas nodarīts līdz 2013. gada 25. oktobrim, piedziņu. Bet lietām par pacienta dzìvībai vai veselībai nodarìto kaitējumu pēc 2013. gada 25. oktobra ir radīts īpašs administratīvi tiesisks mehānisms jeb pacientu tiesību aizsardzības līdzeklis, jau minētais Ārstniecības riska fonds. Ar jaunā koncepta ieviešanu ir notikusi procesuālo principu izmaiṇa. Civilprocesuālos principus - pušu sacīkstes un pušu līdztiesības - aizstāj objektīvās izmeklēšanas princips un citi administratīvā procesa principi.

Ārstniecības riska fonda vispārējie principi ir noteikti Pacientu tiesību likuma 17. pantā, bet fonda darbību reglamentē ĀRF noteikumi. Ārstniecības riska fonda 
institucionālā uzbūve ir duāla, proti, tā organizāciju nodrošina divas Veselības ministrijas tiešās padotības iestādes:

1) Veselības inspekcija (veic ekspertīzi, sagatavo atzinumu un nosaka kaitējuma apmēru procentos, kā arī vērtē ārstniecības izdevumu saistību ar pacientam nodarītā kaitējuma seku mazināšanu vai novēršanu);

2) Nacionālais veselības dienests (administrē Ārstniecības riska fonda līdzekḷus un, pamatojoties uz inspekcijas atzinumu, pieñem lēmumu par atlīdzỉbas izmaksāšanu vai par atteikumu to izmaksāt, kā arī izmaksā atlīdzību no Ārstniecības riska fonda).

Atbilstoši Pacientu tiesību likuma 17. panta otrajai dạ̣ai Nacionālā veselības dienesta lēmumu un rīcỉbu attiecībā uz pacientam izmaksājamo atlīdzību no Ārstniecības riska fonda var apstrīdēt Veselības ministrijā. Veselības ministrijas lēmumu var pārsūdzēt tiesā Administratīvā procesa likuma noteiktajā kārtībā. Pacientam nav tiesību apstrīdēt Veselïbas inspekcijas atzinumu.

\section{Administratīvais process Veselības inspekcijā}

Būtiskāko Ārstniecības riska fonda darba daḷu paveic Veselības inspekcija, jo svarīgākie jautājumi ir šādi:

- maksāt vai nemaksāt kompensāciju par veselībai nodarīto kaitējumu;

- cik lielai jābūt šai kompensācijai.

Veselïbas inspekcija veic ekspertīzi, sagatavo atzinumu un nosaka kaitējuma apmēru procentos, kā arī vērtē ārstniecības izdevumu saistību ar pacientam nodarìtā kaitējuma seku mazināšanu vai novēršanu.

Apspriežot Veselības inspekcijas atzinuma tiesisko dabu, secināms, ka tas nav nedz administratīvs akts, nedz starplēmums administratīvajā procesā, bet tas ir pierādǐšanas lïdzeklis specifiskā administratīvajā procesā - eksperta atzinums. To galvenokārt raksturo atzinuma autors vai autori - personas ar specifiskām zināšanām, kuras sniedz specifisku viedokli par specifisku gadījumu, kuru novērtējot, nepieciešamas speciālas zināšanas nozarē. Ne Pacientu tiesību likumā, ne ĀRF noteikumos nav paredzēta kārtība, kā rīkoties, ja Veselības inspekcijas sagatavotais atzinums pierādījuma novērtēšanas procesā izrādās nepiel̦aujams vai neticams (domājams, ka par attiecināmību strīdu nebūs). Vispārīgi no administratīvā procesa regulējuma [2] izriet šāda notikuma gaita: ja administratīvā procesa ietvaros iestādē vai tiesā radīsies šaubas par konkrētās ekspertīzes atzinuma piel̦aujamību vai ticamību, Nacionālā veselības dienesta lēmums par atlīdzības izmaksāšanu vai par atteikumu izmaksāt atlīdzību ir atcel̦ams, un administratīvais process ir jāsāk no jauna.

Administratīvā procesa sākumā Veselības inspekcija savāc informāciju, iepazīstoties ar dokumentiem, kas saṇemti no iesniedzēja, un pieprasot no ārstniecības iestādēm pacienta mediciniskos dokumentus. 
Informācijas ieguves procesā Veselības inspekcija ir tiesīga pieaicināt citas ārstniecības personas, to skaitā ārstniecības personu profesionālo asociāciju pārstāvjus un galvenos speciālistus. Kaut arī ĀRF noteikumos nav konkrēti norādīta šo pieaicināto personu loma, tomēr atbilstīgi ratio legis šĩs personas ir eksperti, kam būtu jādod atzinums par specifiskiem, ar medicinnas zinātni saistītiem jautājumiem konkrētā lietā. ĀRF noteikumi nesatur kādu regulējumu par prasībām pieaicināmiem ekspertiem, arī prasībām pēc neitralitātes un neieinteresētības konkrētā lietā vai attiecībā uz ekspertu kompetenci. Atzīmējams, ka ĀRF noteikumi nesatur kādu regulējumu par ekspertu pienākumiem un atbildību par informācijas apjomu, ar ko Veselïbas inspekcija iepazīstina pieaicinātos ekspertus, t. sk. ekspertu atbildību par dienesta un sensitīvās informācijas saglabāšanu noslēpumā. Pašreiz pastāv iespēja, ka Veselības inspekcija var pieaicināt ekspertu, kurš var būt ieinteresēts lietas iznākumā un kuru, visticamāk, iepazīstinās ar sensitīvu un aizsargājamu informāciju, bet viņš netiks brīdināts par atbildību, ja šo informāciju izpaudīs. Jāuzsver (vai jānorāda), ka atlīdzības prasījuma iesniedzējs netiek informēts par pieaicināmiem ekspertiem un iesniedzējam nav tiesību izteikt viedokli vai pieteikt noraidijumu.

Zinātniskajā literatūrā, raksturojot Latvijas "medicīnas lietu" nākotni, norādīts, ka jāveido starptautiskas ekspertu komisijas, jo Latvija ir ḷoti maza valsts un pieaicināmo ekspertu skaits ir stipri ierobežots [11,238]. Šis viedoklis ḷoti trāpīgi raksturo Latvijas situāciju, un tādēḷ sevišķi būtiski ir ÂRF noteikumos paredzēt konkrētu ekspertu atbilstības regulējumu.

Šeit minētais ir vērtējams kā Ārstniecības riska fonda regulējuma trūkumi, kas jānovēršs, veicot atbilstošus grozījumus ĀRF noteikumos.

ĀRF noteikumu 8.3. punktā ir paredzētas Veselības inspekcijas tiesības "pieprasīt, lai komisija (ne mazāk kā triju ārstniecības personu sastāvā, ja nepieciešams, pieaicinot speciālistus no citām ārstniecības iestādēm), ko izveidojis tās ārstniecības iestādes vadītājs, par kuru ir saṇemts atlīdzības prasijjuma iesniegums, veiktu izvērtējumu un sniegtu inspekcijai viedokli par kaitējuma esību vai neesību un kaitējuma apmēru". Pētījuma autoru vērtējumā šāds noteikums vērsts uz to, lai pārkāpējs pats novērtētu savu kḷūdu, tāpēc tas ir nekas cits kā likumdošanas brāḳis. Jau romiešu tiesībās tika attīstīts procesuālais princips nemo iudex in causa sua (neviens nav tiesnesis paša lietā). Autoru ieskatā, šì norma neatbilst tiesībām uz taisnīgu tiesu saturu (Latvijas Republikas Satversmes 92. pants [15] un Cilvēka tiesību un pamatbrīvību aizsardzības konvencijas 6. pants) [6].

Veselības inspekcijā, veicot ekspertīzi, ir paredzēts ekspertēt tikai pacienta medicīniskos dokumentus, bet nav paredzēta iespēja veikt paša pacienta apskati un iztauju. Pēc būtības šajā procesā pacients var izteikties tikai vienu reizi - iesniedzot iesniegumu Nacionālajā veselības dienestā. Minētajā saskatāma objektīvās izmeklēšanas principa ignorēšana. Šis regulējums sašaurina pacientu tiesības uz atlīdzību tādējādi, ka atṇem šai procedūrai objektivitāti. 


\section{Cēloṇsakarība starp kaitējumu personai un sniegto veselības aprūpi}

Ārstniecības riska fonda mērḳis, kas definēts direktīvā 2011/24/ES, ir nodrošināt, lai pacientiem ir pieejamas pārredzamas sūdzību procedūras un mehānismi, kas dod viniiem iespēju lūgt aizsardzības līdzekḷus saskaṇā ar dalībvalsts tiesību aktiem, ja sniegtās veselïbas aprūpes dēl ir nodarìts kaitējums.

Jāapskata, kā tiek konstatēta cēlon,sakarība starp kaitējumu personai un sniegto veselības aprūpi.

ĀRF noteikumos ir paredzēts, ka Nacionālais veselības dienests pieṇem lēmumu par atteikumu izmaksāt atlīdzību, ja nav konstatēta cēloṇsakarība starp kaitējumu un ārstniecības personas veikto darbỉbu vai bezdarbību ārstniecības procesā. Cēloṇsakarības esamību vai neesamību konstatē Veselības inspekcija.

Tas, ka jāpārbauda, vai konkrētā rīcība ir izraisījusi konkrētas negatīvas sekas, jau romiešu tiesībās ieguva formulu conditio sine qua non (priekšnoteikums, bez kura nē). Ar šīs formulas palīdzību arī mūsdienās noskaidro tos apstākḷus, bez kuriem kaitīgais notikums nevarētu iestāties, tātad - kuri ir cēloniskā sakarā ar nodarījumu [28]. Šì koncepcija ir atrodama arī ĀRF noteikumos, kuru 12.1. punktā paredzēts, ka Nacionālais veselības dienests pieṇem lēmumu par atteikumu izmaksāt atlīdzību, ja nav konstatēta cēlon, sakarība starp kaitējumu un ārstniecības personas veikto darbību vai bezdarbību ārstniecības procesā.

Eiropas valstīs, piemēram, Vācijā, Apvienotajā Karalistē, Francijā, Spānijā un Itālijā, šis princips darbojas krimināltiesībās [11, 100]. Pierādī̌anas teorijā pastāv jēdziens "pierādī̌̌anas standarts", kas attiecas uz līmeni vai pakāpi, kādā jābūt ìstenotai pierādīšanas nastai. Tas ir pārliecības vai iespējamības līmenis, ko pierādījumiem jārada fakta izlēmēju prātā; tas ir standarts, kādā fakta izlēmējiem ar pierādījumu starpniecību jātiek pārliecinātiem no tās strīdus puses, uz kuru gulstas pierādīšanas nasta [26, 150-151]. Pierādīšanas standarta veidi ir "ārpus saprātīgām šaubām" un "iespējamību pārsvars". Pierādīšanas standartu "ārpus saprātīgām šaubām" izmanto procesos, kuros kā procesuālais princips darbojas nevainīguma prezumpcija, kas arī nosaka šì pierādīšanas standarta saturu. Latvijā to lieto kriminālprocesā un administratīvo pārkāpumu procesā (t. s. "mazajā kriminālprocesā"), kur pierādīšanu realizē apsūdzības puse. Savukārt kriminālprocesā un administratīvo pārkāpumu procesā, kur pierādīšanas nasta ir pārnesta uz aizstāvības pusi, lieto pierādīšanas standartu "iespējamais pārsvars" [26, 151-154]. Šo pierādīšanas standartu lieto arī civillietās, un, pēc autoru domām, tas ir lietojams arī administratīvajā procesā, t. sk. administratīvajā procesā Ārstniecības riska fonda ietvaros. Tas nozīmē, ka cēloṇsakarības konstatēšanas formula conditio sine qua non nav lietojama, konstatējot cēloṇsakarību starp kaitējumu un ārstniecības personas veikto darbību vai bezdarbību ārstniecības procesā.

Eiropas tiesiskajā telpā ir izstrādāts doktrināls dokuments Eiropas deliktu tiesību principi (The Principles of European Tort Law, turpmāk - EDTP) [27], kam gan tiešas 
piemērojamības nav, bet kas var kalpot kā doktrināls avots. EDTP paredz tādus cēlonības veidus kā vienlīdz nozīmīgi (konkurējoši) cēloṇi (EDTP 3:102. pants), alternatīvie cēloṇi (EDTP 3:103. pants), potenciālie cēloṇi (EDTP 3:104. pants) un nenoteikta daḷeja cēlonība (EDTP 3:105. pants) [27]. Šie Eiropas deliktu tiesību principos norādìtie cēlonības konstatēšanas veidi būtu lietojami, konstatējot cēloṇsakarību starp kaitējumu un ārstniecības personas veikto darbïbu vai bezdarbību ārstniecības procesā. Autoriem uz šĩ raksta sagatavošanas brīdi nav ziṇu, kādus cēlonības veidus respektē Veselības inspekcija, veicot ekspertīzes, bet šis jautājums ir turpmāko pētījumu darba kārtībā.

ĀRF noteikumos ir paredzēts, ka Nacionālais veselības dienests pieṇem lēmumu par atteikumu izmaksāt atlīdzību, ja orgānu vai audu anatomisks bojājums vai funkciju traucējums ir saistīts ar veikto ārstniecību, taču nav radies ārstniecības personas neprofesionālas rīcības dēḷ. Minēto apstākli konstatē Veselības inspekcija. Pacientu tiesību likuma 16. panta pirmajā dạ̦ā paredzēts, ka pacientam ir tiesības uz atlīdzỉbu par viṇa dzīvībai vai veselībai nodarīto kaitējumu (arī morālo kaitējumu), kuru radījuši apstākḷi ārstniecības laikā. Minētais apstāklis var rasties, piemēram, no klīniskās infekcijas, kuras izcelsmē nebūs iespējams vainot ārstniecības personas neprofesionālu rīcību, vai arī, piemēram, jatrogēnas kḷūdas dēḷ.

Pēc profesora A. Lieljukša iedalījuma izšķir kḷūdas, ko pacienta veselības aprūpē piel̦auj ārstniecības persona, un tās ir šādas: deontoloǵiskas kḷūdas, diagnostikas kḷūdas, ārstniecības kḷūdas. Papildus šìm profesors A. Lieljuksis min arī jatrogēnas kḷùdas, t. i., kḷūdas, kuras veselības aprūpes procesā piel̦āvusi ārstniecības persona, bet kuras nav bijušas novēršamas $[20,679]$.

Deontologiskās kḷūdas (saistîtas ar ārstniecības personu saskarsmi un attieksmi pret pacientiem un uzvedības normu pārkāpšanu attiecībā pret pacientiem) arī var būt vismaz "nenoteiktā daḷējā cēlonībā" (EDTP 3:105. pants) ar pacienta veselībai nodarīto kaitējumu, jo medicīnas zinātnē ir atzīts, ka psihosomatiskie mehānismi var izraisīt pacienta veselības stāvokḷa pasliktināšanos [3].

Diskutējams ir jautājums, vai diagnostikas kḷūdas vienmēr izcelsies ārstniecības personas neprofesionālas rīcības dēḷ. Minēto kḷūdu cēlonis var būt gan kḷume diagnostikas iekārtās, gan objektīvi nepietiekamu zināšanu vai pētījumu dēl, gan iespējami citi cēloṇi, bet ne ārstniecības personas neprofesionāla rīcība. Tomēr tieši diagnostikas kḷūdas var būt iemesls kaitējumam sniegtās veselības aprūpes dēḷ. ĀRF noteikumu 12.2. punkta norma izslēdz pacienta tiesības uz atlīdzību diagnostikas un jatrogēno kḷūdu gadījumā.

Zviedrijā, kuras modelis n,emts par paraugu Ārstniecības riska fonda izveidei Latvijā, tiek kompensēti zaudējumi, kas radušies:

- nepareizas veselības aprūpes (pacienta izmeklēšanas, aprūpes, ārstēšanas vai līdzīga pasākuma) dēḷ ar prezumpciju, ka varēja no kaitējuma izvairīties, ja jautājums ir neskaidrs;

- medicīnas tehnikas vai slimnīcu aprīkojuma dēli;

- nepareizas diagnozes rezultātā; 
- infekcijas, kas radusies pacienta izmeklēšanas, aprūpes, ārstēšanas vai līdzīga pasākuma dēl;

- negadījuma dēl, kas noticis saistībā ar pacienta izmeklēšanu, aprūpi, ārstēšanu vai līdzīgu pasākumu vai pacienta transportēšanas laikā, vai saistībā ar ugunsgrēku, vai citu bojājumu veselības aprūpes telpām un aprīkojumam;

- pārkāpuma vai farmācijas priekšrakstu neievērošanas rezultātā [29].

Redzams, ka Zviedrijas likumā par pacientam nodarìto kaitējumu (patientskadelag), atškirīibā no ĀRF noteikumiem, paredzētas gan deontologiskas kḷūdas, diagnostikas kḷūdas un jatrogēnas kḷūdas, kā arī dažādi apstākḷi ārstniecības laikā visplašākajā nozīmē.

Tādēl secināms, ka ĀRF noteikumu 12.1. punkts un 12.2. punkts nepamatoti sašaurina Pacientu tiesību likuma 16. panta pirmās daḷas tvērumu, no kompensācijas mehānisma izslēdzot deontologiskas kḷūdas, diagnostikas kḷūdas un jatrogēnas kḷūdas, kā arī apstākḷus ārstniecības laikā.

Tāpat secināms, ka direktīva 2011/24/ES ir implementēta nepilnīgi, jo dalībvalstīm savos normatīvajos un administratīvajos aktos bija jāparedz pieejamas sūdzību procedūras un mehānismi, ja sniegtās veselības aprūpes dēl ir nodarìts kaitējums, nesašaurinot cietušo pacientu tiesības uz atlīdzību ar noteikumiem par cēlon,sakarības esamību starp kaitējumu un ārstniecības personas veikto darbību vai bezdarbību ārstniecības laikā.

\section{Kompensācijas apmērs}

Līdz Ārstniecības riska fonda koncepta ieviešanai strīdus par pacientu veselībai nodarīto kaitējumu izskatīja vispārējās jurisdikcijas tiesa civilprocesuālā kārtībā. Šajos gadījumos kompensāciju maksāja ārstniecības iestādes vai ārstniecības personas, vai apdrošinātājs, ja atbilstoši līgumam iestājās apdrošināšanas gadījums. Kompensāciju par pacientu veselībai nodarìto kaitējumu bija iespējams pieteikt vienlaikus ar krimināllietas iztiesāšanu apsūdzībās pēc Krimināllikuma 138. panta pirmās vai otrās daḷas. Atsevišķos gadījumos tas arī tika darīts, bet tomēr tas nebija ìpaši populāri, jo piedzìt ievērojamu kompensāciju no fiziskas personas varēja izrādīties nereāli.

Ārstniecības riska fonda koncepts, darbojoties pēc obligātās apdrošināšanas principiem, izslēdz arī ārstniecības iestāžu un ārstniecības personu nelabvēlīgu mantisku risku Pacientu tiesību likuma 16. panta otrajā dalıā noteikto limitu robežās (par pacienta dzīvībai vai veselībai nodarīto kaitējumu (arī morālo kaitējumu) - ne vairāk kā 142290 eiro, par pacientam radītiem ārstniecības izdevumiem - ne vairāk kā 28460 eiro). Tomēr šeit ir jāpakavējas pie jautājuma, kāda varētu būt pacienta potenciālā rīcība, ja viṇš uzskata, ka Pacientu tiesību likuma 16. panta otrajā dạ̦ā noteiktie limiti nekompensē nodarīto kaitējumu pilnā apmērā. Šādā gadījumā pacients varētu vērsties civilprocesuālā kārtībā ar prasību tiesā. Tāpēc secināms, ka ārstniecības iestādes un personas no negatīvajām mantiskajām sekām profesionālas neveiksmes vai neuzmanības dēl 
tiks pasargātas tikai gadījumos, ja cietušie pacienti būs apmierināti ar Ārstniecības riska fonda izmaksāto summu.

Vienlaikus jāatceras, ka Ārstniecības riska fonda mērḳis, kas definēts direktīvā, ir nodrošināt, ka pacientiem ir pieejamas pārredzamas sūdzību procedūras un mehānismi, kas dod viniiem iespēju lūgt aizsardzības līdzekḷus saskañā ar dalībvalsts tiesību aktiem, ja sniegtās veselības aprūpes dēl ir nodarīts kaitējums. Š́is direktīvas mērḳis netiek sasniegts, ja Pacientu tiesību likuma 16. panta otrajā dạ̦ā noteiktie limiti nekompensē pacientam nodarīto kaitējumu pilnā apmērā, un šāda situācija var izveidoties nosacītās "dzīiìbas cenas" gadījumā - 142290 eiro apmērā.

Kompensācijas apmēra jautājums ir cieši saistīts ar tās noteikšanas kritērijiem. ĀRF noteikumos paredzēts, ka kaitējuma (arī morālā kaitējuma) smaguma pakāpi procentos inspekcija nosaka atbilstoši ĀRF noteikumu 2. pielikumam, n,emot vērā ĀRF noteikumu 9. punktā noteiktos kritērijus, un tie ir šādi:

- veselības stāvoklis, slimības raksturs un smagums ārstniecības procesa sākumā;

- slimības paredzamā norises gaita, veicot atbilstošu ārstēšanu, un cēloṇsakarība starp ārstniecības personas darbību vai bezdarbību un ārstniecíbas rezultātā radušos kaitējumu;

- pacienta līdzdalība (līdzestība) savas veselības aprūpē, tās nozīme un ietekme uz ārstniecíbas procesa norisi;

- kaitējuma smagums kopsakarā ar nepieciešamās ārstēšanās ilgumu un ārstēšanās izdevumiem;

- ārstniecības procesā radušies neparedzamie veselïbas traucējumi, kas ir vai nav saistāmi ar konkrētās saslimšanas ārstēšanu, ārstniecības personas darbību vai bezdarbïbu;

- ārstniecības personas ieguldỉjums pacienta veselības stāvokḷa uzlabošanā, atjaunošanā;

- apstākḷi un vide ārstniecības iestādē;

- cik pilnīgi un pienācīgi ārstniecības persona veica savus pienākumus pacienta ārstēšanas laikā;

- vai ārstniecības iestādei ir bijuši pieejami visi nepieciešamie resursi, lai novērstu kaitējuma rašanās cēloni;

- ārstniecības personas darbības atbilstība Ārstniecības likuma 9.1. panta pirmajai daliai.

ĀRF noteikumu anotācijā [21] nav atrodams izskaidrojams, pēc kādiem principiem tika atlasīti noteikumu 9. punktā norādītie kritēriji. Daži no tiem izsauc neizpratni, jo kā gan pacienta tiesības uz atlīdzību varētu ietekmēt "apstākḷi un vide ārstniecības iestādē" vai arī kritērijs "vai ārstniecības iestādei ir bijuši pieejami visi nepieciešamie resursi, lai novērstu kaitējuma rašanās cēloni”. Ja pacienta veselībai ir nodarīts kaitējums un tas ir cēloniskā sakarā ar apstākḷiem ārstniecības laikā (kā tas noteikts Pacientu tiesību likuma 16. pantā), vai pacients būtu vainojams, ka viṇš iestājies ārstniecības iestādē, kurā "apstākḷi un vide" ir slikti vai gluži pretēji - labi? Tāpat - vai un kā pacients var ietekmēt to, vai 
“ārstniecỉbas iestādei ir bijuši pieejami visi nepieciešamie resursi, lai novērstu kaitējuma rašanās cēloni"? Diskutējams ir jautājums par to, vai ir jāvērtē "ārstniecības personas ieguldījums pacienta veselības stāvokḷa uzlabošanā, atjaunošanā", "cik pilnīgi un pienācīgi ārstniecības persona veica savus pienākumus pacienta ārstēšanas laikā", vai "ārstniecības personas darbỉbas atbilstība Ārstniecības likuma 9.1. panta pirmajai daḷai”, kurā noteikts: "Ārstniecību veic atbilstoši klīniskajām vadlīnijām vai ārstniecībā izmantojamo metožu un zāḷu lietošanas drošības un ārstēšanas efektivitātes novērtējumam, kas veikts, ievērojot uz pierādījumiem balstìtas medicīnas principu". Šie pēc būtības ir ārstniecības personas pienākumi. Ja, veicot ārstniecību, viss tika darīts atbilstoši vislabākajai sirdsapziṇai, labai klīniskajai praksei un vadlīnijām, kā arī ievērojot uz pierādījumiem balstītas medicīnas principu, bet pacienta veselïbai vienalga ir nodarîts kaitējums, vai šis gadījums nav tāds, lai saṇemtu atlīdzību no Ārstniecības riska fonda, kas pēc būtības ir valsts regulēta un specifiska apdrošināšana. Tādēḷ autori ierosina svìtrot ĀRF noteikumu 9. punkta 6.-10. apakšpunktu kā neatbilstošus ĀRF koncepta būtỉbai.

ĀRF noteikumu 2. pielikumā ir noteikts aptuvenā nodarītā kaitējuma smaguma apmērs procentos. Ja nav laikus diagnosticēta saslimšana un (vai) nav nodrošināta adekvāta ārstēšana, un tas izraisīja pacienta nāvi, nodarītā kaitējuma smaguma apmērs tiek noteikts no 0 līdz 100 procentiem. Attiecībā uz citiem nodarìtā kaitējuma veidiem smaguma apmērs tiek noteikts no $0 \%$ līdz $30 \%, 50$ \%, 70 \% vai $100 \%$. Kā redzams, nodarìtā kaitējuma smaguma apmēri ir neskaidri, bez labi saprotamiem piemērošanas noteikumiem, un tie nenodrošina, lai līdzīgos un salīdzināmos gadījumos nodarītā kaitējuma smaguma apmērs būtu līdzvērtīgs. Arī ĀRF noteikumu 9. punktā norādìto kritēriju ietekme uz kaitējuma smaguma procentuālo apmēru ir nekonkrēta un atstāta Veselības inspekcijas kā tiesību piemērotāja ziṇā.

Normatīvajos aktos, kas regulē līdzīgas tiesiskās attiecỉbas, proti, Ministru kabineta 2014. gada 17. jūnija noteikumos Nr. 340 "Noteikumi par apdrošināšanas atlīdzības apmēru un aprēḳināšanas kārtību par personai nodarītajiem nemateriālajiem zaudējumiem" [23] (turpmāk - apdrošināšanas atlīdzības noteikumi) ir noteikta konkrēta apdrošināšanas atlīdzības apmēra aprēķināšanas kārtība, neatstājot vietu diskusijām un neskaidriem kritērijiem, kuru piemērošanas metodologiija nav saprotama. Apdrošināšanas atlīdzỉbas noteikumos atlīdzību aprēḳina atbilstoši miesas bojājumu smagumu pakāpei, katru miesas bojājumu smaguma pakāpi piesaistot konkrētam minimālo mēnešalgu skaitam. Piemēram, ja cietušajai personai ir smagi miesas bojājumi, t. s. bāzes likme ir 25 minimālo mēneša darba algu apmērā, ja vidēji miesas bojājumi - 15 minimālo mēneša darba algu apmērā, ja viegli miesas bojājumi - piecu minimālo mēneša darba algu apmērā, bet, ja miesas bojājumi rada veselības traucējumu līdz sešām dienām, t. i., nesasniedz vieglu miesas bojājumu pakāpi, pien,em, ka t. s. bāzes likme ir vienas minimālās mēneša darba algas apmērā. Papildu šai kompensācijas daḷai saskaṇā ar tabulā norādītiem atlīdzỉbas aprēḳināšanai piemērojamiem procentiem tiek aprēḳināta kompensācijas dạ̦a par katru miesas bojājuma veidu, piemēram, par konkrētu kaulu lūzumiem, konkrētu audu un orgānu bojājumiem, kas izsauc funkciju traucējumus, reizinot to ar bāzes koeficientu 
10 minimālo mēneša darba algu apmērā. Atsevišķi kritēriji ir noteikti par cietušās personas sāpēm un garīgajām ciešanām sakropḷojuma vai invaliditātes dēḷ, kā arī saistībā ar apgādnieka, apgādājamā vai laulātā nāvi vai 1. grupas invaliditāti. Šo apdrošināšanas atlīdzības noteikumu pielikumā minētie apdrošināšanas atlīdzības aprēkināšanai piemērojamie procenti tika noteikti, n,emot vērā nelaimes gadījumu apdrošināšanā piemērojamos procentus, Valsts darba nespējas ārstu ekspertīzes komisijas noteiktos invaliditātei piemērojamos procentus un Tiesu medicīnas ekspertīzes praksē piemērojamos procentus [22].

Zinātniskajā literatūrā tiek pausts viedoklis, ka apdrošināšanas atlīdzības noteikumi satur l̦oti detalizētu personai radīto miesas bojājumu gradāciju un metodologiiju, kurai atbilstoši teorētiski būtu iespējams aprēḳināt kompensācijas apmēru visās lietās, kurās personām prettiesiskas rīcības rezultātā nodarīti miesas bojājumi un radīts nemantiskais kaitējums, un tādēl nebūtu pamata uzskatìt, ka šajos noteikumos atrodamo kritēriju un metodologiijas izmantošana nevarētu tikt piemērota arī attiecībā uz citām tiesiskajām attiecībām [13]. Pēc autoru domām, nedrīkst aizmirst, ka apdrošināšanas atlīdzības noteikumu regulētā situācija attiecas uz negadījumiem ceḷu satiksmē, kur atbildība par sekām iestājas atbilstoši stingrās atbildības (strict liability) konceptam. Apdrošināšanas atlīdzības noteikumos paredzētā metodologiija nebūtu piemērojama attiecībā uz tīšos noziedzīgos nodarījumos cietušajiem. Arī medicīna ir sarežg̀itāka joma, salīdzinot ar ceḷu satiksmes negadījumiem. Nosakot kompensācijas apmēru, ir jānnem vērā ĀRF noteikumu 9. punktā noteiktie kritēriji, ỉpaši, pacienta līdzdalība (līdzestība) savas veselības aprūpē, tās nozìme un ietekme uz ārstniecības procesa norisi. Tādēḷ apdrošināšanas atlīdzības noteikumi nav izmantojami, nosakot atlīdzību par pacienta dzīvībai vai veselībai nodarìto kaitējumu, bet šie apdrošināšanas atlīdzības noteikumi ir labs paraugs, kā var metodoloǵiski un detalizēti izveidot atlīdzības (kompensācijas) aprēḳināšanas modeli. Pētāmā jautājuma kontekstā secināms, ka ĀRF noteikumi nesatur salīdzināmas detalizācijas pakāpes metodologiju.

Latvijas Republikas Augstākās tiesas tiesu prakses apkopojuma "Tiesu prakse par morālā kaitējuma kompensāciju kriminālprocesā 2010/2011" 3. pielikumā ir tabula, kurā norādītas rekomendējamās summas, kuras "tiesas varētu piedzìt" [14]. Arī citās Eiropas valstīs pieeja ir līdzīga. Itālijā, Spānijā un Francijā kompensāciju par nemantisku kaitējumu nosaka ar speciālu tabulu palīdzību, bet Vãcijā un Apvienotajā Karalistē, kur arī ir tabulas, tās atškiriībā no pirmās valstu grupas, veido nevalstiskais sektors [1].

Latvijas tiesiskajā telpā pastāv strīdi, vai apdrošināšanas atlīdzības noteikumos ietvertā konkrētā metodologija nerada ierobežojumus izmaksājamās atlīdzības apmēriem [19], jo morālās kompensācijas apmērs ir saistīts ar personas subjektīvo pašnovērtējumu. Arī pēc autoru domām, ir diezgan dīvaini konstatēt, ka cilvēka dzīvības cena atbilstoši Pacientu tiesību likuma 16. panta otrās dal̦as pirmajam punktam ir "ne vairāk kā 142290 eiro". Tomēr, pēc autoru ieskata, šì t. s. konkrētās metodologijas jeb "tabulu" pieeja, ko kritizē ne tikai Latvijā un kas nepārprotami novienādo cietušos neatkarīgi no subjektīvā pašnovērtējuma, rada tik ḷoti nepieciešamo tiesisko stabilitāti un tiesu prakses 
prognozējamību, kas ir lielāks ieguvums, salīdzinot ar "tiesas ieskata" pieeju. Strīdi par to, kura pieeja ir labāka, tik drīz nerims. Vācijā kritika tiek veltīta arī tam, kādi spriedumi tiek iekḷauti "sāpju naudas tabulās" (Schmerzensgeldtabellen), norādot, ka tām nav ne zinātniska, ne statistiska pamatojuma [25]. Arī Latvijā - Pacientu tiesību likuma anotācijā [16] - nav atrodams pamatojums, kādēl atlīdzības apmērs ir tieši tāds, kā noteikts likumā.

Tiesiskās skaidrības dēḷ ĀRF noteikumi būtu jāgroza, nosakot, kā konkrēti ĀRF noteikumu 9. punktā norādītie kritēriji ietekmē kaitējuma smaguma procentuālo apmēru.

\section{Secinājumi}

Veselïbas inspekcijas atzinums, kas gatavots Ārstniecības riska fonda procesā, ir pierādīšanas līdzeklis specifiskā administratīvajā procesā.

Ja administratīvā procesa ietvaros iestādē vai tiesā radīsies šaubas par konkrētās ekspertīzes atzinuma piel̦aujamību vai ticamību, ir atcel̦ams Nacionālā veselības dienesta lēmums par atlīdzības izmaksāšanu vai par atteikumu izmaksāt atlīdzību, un administratīvais process jāuzsāk no jauna.

Ārstniecības riska fonda darbības noteikumi nesatur kādu regulējumu par ekspertu pienākumiem un atbildību par informācijas apjomu, ar ko Veselïbas inspekcija iepazīstina pieaicinātos ekspertus, kā arī ekspertu atbildību par dienesta un sensitīvās informācijas saglabāšanu noslēpumā.

Iesniedzējs netiek informēts par pieaicināmiem ekspertiem, un viṇam nav tiesību izteikt viedokli vai pieteikt noraidījumu. Šeit minētais ir vērtējams kā Ārstniecības riska fonda darbības noteikumu regulējuma trūkumi, kas būtu jānovērš, veicot atbilstošus grozījumus Ārstniecības riska fonda darbības noteikumos.

Ārstniecības riska fonda darbības noteikumu 8.3. punkta tiesību norma ir vērsta uz to, lai pārkāpējs pats novērtētu savu kḷūdu. Tas ir pretrunā ar procesuālo tiesību principu nemo iudex in causa sua (neviens nav tiesnesis paša lietā). Tādēl konkrētais regulējums fundamentāli pārkāpj Latvijas Republikas Satversmes 92. pantā nostiprinātās tiesības uz taisnīgu tiesu.

Veselības inspekcijā, veicot ekspertīzi, ir paredzēts ekspertēt tikai pacienta medicīniskos dokumentus, bet nav paredzēta iespēja veikt paša pacienta apskati un iztauju. Minētajā saskatāma objektīvās izmeklēšanas principa ignorēšana, kas atṇem šai tiesiskajai procedūrai objektivitāti.

Eiropas deliktu tiesību principos norādītie cēlonības konstatēšanas veidi būtu lietojami, konstatējot cēloṇsakarību starp kaitējumu un ārstniecības personas veikto darbību vai bezdarbību ārstniecības procesā.

Ārstniecības riska fonda darbïbas noteikumu 12.1. punkts un 12.2. punkts nepamatoti sašaurina Pacientu tiesību likuma 16. panta pirmās daḷas tvērumu, no kompensācijas mehānisma izslēdzot deontologiskas kḷūdas, diagnostikas kḷūdas un jatrogēnas kḷūdas, kā arī apstākḷus ārstniecības laikā. 
Direktīva 2011/24/ES ir implementēta nepilnīgi, jo dalïbvalstīm savos normatīvajos un administratīvajos aktos bija jāparedz pieejamas sūdzību procedūras un mehānismi, ja sniegtās veselības aprūpes dēl tiek nodarìts kaitējums, nesašaurinot cietušo pacientu tiesības uz atlīdzību ar noteikumiem par cēlon, sakarības esamību starp kaitējumu un ārstniecības personas veikto darbību vai bezdarbību ārstniecības laikā.

Direktīvas mērḳis netiek sasniegts, ja Pacientu tiesību likuma 16. panta otrajā dạ̦ā noteiktie limiti nav pietiekami, lai kompensētu pacientam nodarìto kaitējumu pilnā apmērā, un šāda situācija var izveidoties gadījumā ar nosacìto "dzīvības cenu" 142290 eiro apmērā.

Ārstniecības iestādes un personas no negatīvajām mantiskajām sekām profesionālas neveiksmes vai neuzmanības dēl tiks pasargātas tikai gadījumos, ja cietušo pacientu apmierinās no Ārstniecības riska fonda izmaksājamās summas.

Ārstniecības riska fonda darbïbas noteikumu 9. punkta 6.-10. apakšpunkts neatbilst Ārstniecības riska fonda koncepta būtībai, tādēl jāsvītro no noteikumiem.

Ārstniecības riska fonda darbības noteikumi nesatur salīdzināmas detalizācijas pakāpes metodologiiju par dažādu kritēriju piemērošanu, nosakot atlīdzību par pacienta dzīvībai vai veselībai nodarīto kaitējumu. Tie nenodrošina, lai līdzīgos un salīdzināmos gadījumos nodarītā kaitējuma smaguma apmērs būtu līdzvērtīgs.

Ārstniecības riska fonda darbības noteikumu 9. punktā norādīto kritēriju ietekme uz kaitējuma smaguma procentuālo apmēru ir nekonkrēta. Tiesiskās skaidrības dēl Ārstniecības riska fonda darbības noteikumi būtu jāgroza, nosakot, kā konkrēti Ārstniecības riska fonda darbības noteikumu 9. punktā norādītie kritēriji ietekmē kaitējuma smaguma procentuālo apmēru.

Konkrētas metodolog̣ijas pieeja, kas novienādo cietušos neatkarīgi no subjektīvā pašnovērtējuma, rada tiesisko stabilitāti un tiesu prakses prognozējamību, kas ir lielāks ieguvums, salīdzinot ar "tiesas ieskata" pieeju.

\section{Weaknesses in the Functioning of the Medical Treatment Risk Fund}

\section{Abstract}

Directive 2011/24/EU of the European Parliament and of the Council of $9^{\text {th }}$ March 2011 on the application of patients' rights in cross-border healthcare determines the obligation of the Member State to ensure that the patient is allowed to use transparent complaint procedures and mechanisms, which provides opportunities for the patients to request remedies in accordance with the healthcare legislation of the Member State in case the healthcare provided had caused damages. This concept of the Medical Treatment Risk Fund in Latvia was introduced on $25^{\text {th }}$ October 2013 by taking example from Sweden and Denmark. By $17^{\text {th }}$ October 2013 Cabinet Regulations 
rule amendments in the Law on the Rights of Patients were made, which generally determines the protection of patients' rights in the Medical Treatment Risk Fund principles, but its operations were regulated by $5^{\text {th }}$ November 2013 Cabinet Regulations rules - the Operating Rules of the Medical Treatment Risk Fund. This regulation ensures the right of patients to be reimbursed for the harm caused to life or health.

The activity of the Medical Treatment Risk Fund ensures two direct subordination institutions of the Ministry of Health: The National Health Service and Health Inspection.

In this research, the procedural order of the Medical Treatment Risk Fund is being analysed, specifically the causality between the harm to the patient and the healthcare as well as the question determination of sufficient amount of refund.

Several problem questions had been identified and the conclusions were drawn about implementation of the concept of the Medical Treatment Risk Fund compliance with the Directive 2011/24/EU of the European Parliament and of the Council of $9^{\text {th }}$ March 2011 on the application of patients' rights in cross-border healthcare: the requirements of the Directive have not been implemented correctly; the regulations of the Medical Treatment Risk Fund does not comply with the Law on the Rights of Patients regulation and procedural principles, which provides the rights of the individuals for a fair trial. The author also proposes amendments in order to improve the regulation of the Medical Treatment Risk Fund.

Keywords: Medical treatment risk fund, the right of patients to reimbursement.

\section{Literatūra}

1. A Comparison of compensation for personal injury claims in Europe. GenRe Publications. January 2014. Iegūts no: http://www.genre.com/knowledge/publications/claimsfocus-pc201309-en.html [sk. 26.09.2016.].

2. Administratīiā procesa likums: Latvijas Republikas likums: pieṇemts 25.01.2001. un stājas spēkā 01.02.2004., grozījumi pieṇemti 19.09.2013. Latvijas Vēstnesis. 188(4994), 26.09.2013. [sk. 26.09.2016.].

3. Ancāne, G. Kermeṇa un psihes saistība. Psihologijas Pasaule. 2004, 1, 38-43.

4. Ārstniecības likums: Latvijas Republikas likums: pieṇemts 12.07.1997. un stājas spēkā 01.10.1997., ar grozījumiem, kas pieṇemti līdz 18.06.2015. Latvijas Vèstnesis. 194(5254), 01.10 .2014 .

5. Ārstniecības riska fonda darbības noteikumi: LR Ministru kabineta noteikumi: pieñemti 05.11.2013. un stājas spēkā 23.11.2013. Latvijas Vēstnesis. 228(5034), 22.11.2013.

6. Cilvēka tiesību un pamatbrīvību aizsardzības konvencija, daudzpusējs starptautisks dokuments: pieṇemts 04.11.1950. un stājas spēkā 27.06.1997. Latvijas Vēstnesis. 143/144 (858/859), 13.06.1997. Iegūts no: http://likumi.lv/ta/lv/starptautiskie-ligumi/id/649 [sk. 26.09.2016.].

7. Civillikums: Latvijas Republikas likums: pieṇemts 28.01.1937. un atjaunots spēkā 01.09.1992., ar grozijjumiem, kas pieṇemti līdz 29.10.2015. Latvijas Vēstnesis. 98(5158), 22.05.2014. 
8. Eiropas Komisijas Veselības un pārtikas nekaitīguma generāldirektorāta politikas izklāsts iedal̦as "Sabiedrības veselība" apakšiedaḷā "Pacientu drošums”. Eiropas Komisija. Iegūts no: http://ec.europa.eu/health/patient_safety/policy/index_lv.htm [sk. 26.09.2016.].

9. Eiropas Pacientu tiesību harta. Pacientu ombuds. Iegūts no: http://www.pacientuombuds.lv/ lat/noderiga_informacija/tiesibas___pienakumi/?doc=132 [sk. 26.09.2016.].

10. Eiropas Parlamenta un Padomes 2011. gada 9. marta direktīva 2011/24/ES "Par pacientu tiesību piemērošanu pārrobežu veselības aprūpē”. EUR-Lex. Iegūts no: http://eur-lex.europa. eu/legal-content/LV/TXT/?uri=CELEX\%3A32011L0024 [sk. 26.09.2016.].

11. Ferrara, S. D., Boscolo-Berto, R., Viel, G. Malpractice and Medical Liability. European State of the Art and Guidelines. Berlin, Heidelberg: Springer-Verlag. 2013, 368.

12. Grozijumi Ministru kabineta 2013. gada 5. novembra noteikumos Nr. 1268 "Ārstniecības riska fonda darbības noteikumi”: LR Ministru kabineta noteikumi: pien,emti 19.01.2016. un stājas spēkā 22.01.2016. Iegūts no http://likumi.lv/ta/id/279490-grozijumi-ministru-kabineta-2013-gada-5-novembra-noteikumos-nr-1268-arstniecibas-riska-fonda-darbibasnoteikumi [sk.26.09.2016.].

13. Kubilis, J. Civiltiesiskās atbildības par nemantisko kaitējumu miesas bojājumu gadījumā pilnveidošanas iespējas. Jurista Vãrds. 2016, 37(940), 20-26.

14. Latvijas Republikas Augstākā tiesa. Tiesu prakse par morālā kaitējuma kompensāciju kriminālprocesā (2010-2011). Iegūts no: http://www.at.gov.lv/files/uploads/files/docs/petijumi/ tiesu\%20prakse\%20moralais\%20kaitejums_an.doc [sk. 26.09.2016.].

15. Latvijas Republikas Satversme: LV likums: pieṇemts Satversmes sapulcē 15.02.1922. un stājas spēkā 07.11.1922., ar grozījumiem, kas pien,emti līdz 19.05.2016. Latvijas Vēstnesis. 131(5191), 08.07.2014.

16. Likumprojekta "Pacientu tiesību likums" anotācija. Latvijas Republikas Saeima. Iegūts no: http://titania.saeima.lv/LIVS/SaeimaLIVS.nsf/0/96DC7AFDC685D344C225723E0047B5AC? OpenDocument [sk. 26.09.2016.].

17. Likums "Par prakses ārstiem": Latvijas Republikas likums: pieṇemts 04.04.1997. un stājas spēkā 22.05.1997., ar grozījumiem, kas pien,emti līdz 17.10.2013. Latvijas Vēstnesis. 211(5017), 29.10.2013.

18. Lìgums par Eiropas Savienības darbību. EUR-Lex. Iegūts no: http://eur-lex.europa.eu/legalcontent/lv/TXT/?uri=CELEX\%3A12012E\%2FTXT [sk. 26.09.2016.].

19. Mantrovs, V. EST tiesu prakse nemantiskā kaitējuma atlīdzināšanai OCTA ietvaros: Latvijas problēmjautājumi. Latvijas Universitātes 5. starptautiskās konferences "Juridiskā izglìtība un kultūra: pagātnes mācības un nākotnes izaicinājumi” raksti. Rīga: Latvijas Universitāte, 2014, 560-568.

20. Medicīnas tiesības. Autoru kolektīvs S. Ašnevicas-Slokenbergas zinātniskajā redakcijā. Rīga: Tiesu namu aǵentūra, 2015, 798.

21. Ministru kabineta noteikumu "Ārstniecības riska fonda darbỉbas noteikumi" projekta sākotnējās (ex-ante) ietekmes novērtējuma ziṇojums. LR Veselības ministrija. Iegūts no: http:// www.vm.gov.lv/images/userfiles/phoebe/aktualitates_publiska_apspriesana_6ad08b8ff5eb59 abc2257b0200464.996/vmanot_210513_arf.docx [sk. 26.09.2016.].

22. Ministru kabineta noteikumu projekta "Noteikumi par apdrošināšanas atlīdzības apmēru un aprēḳināšanas kārtību par personai nodarītajiem nemateriālajiem zaudējumiem” sākotnējās ietekmes novērtējuma ziṇojums (anotācija). LR Ministru kabinets. Iegūts no: http://tap. mk.gov.lv/doc/2014_06/FManot_050614_nematr_zaud.1021.DOCX [sk. 26.09.2016.]. 
23. Noteikumi par apdrošināšanas atlīdzības apmēru un aprēḳināšanas kārtību par personai nodarītajiem nemateriālajiem zaudējumiem: LR Ministru kabineta noteikumi Nr. 340 pieṇemti 17.06.2014. Iegūts no: http://likumi.lv/doc.php?id=267451 [sk. 26.09.2016.].

24. Pacientu tiesību likums: Latvijas Republikas likums: pieṇemts 17.12.2009. un stājas spēkā 01.03.2010., ar grozījumiem, kas pieṇemti līdz 17.10.2013. Latvijas Vēstnesis. 211(5017), 29.10.2013.

25. Schmerzensgeldtabellen - Sinnhaftigkeit und Grenzen. Iegūts no: https://ihr-anwalt.com/ blog/verkehrsgerichtstag/schmerzensgeldtabellen/ [sk. 26.09.2016.].

26. Strada-Rozenberga, K. Pierādī̌̌anas teorija kriminālprocesā. Vispārīgā daḷa. Rīga: "Biznesa augstskola Turība", 2002, 296.

27. The Principles of European Tort Law. EGTL. Iegūts no: http://www.egtl.org/Principles [sk. 26.09.2016.].

28. Torgāns, K. Vairāki zaudējumu (kaitējumu) izraisoši cēloṇi. Jurista Vārds. 2007, 28(481).

29. Zviedrijas likums par pacientam nodarìto kaitējumu. Patientskadelag. 1996, 799. Iegūts no: https://www.riksdagen.se/sv/dokument-lagar/dokument/svensk-forfattningssamling/patientskadelag-1996799_sfs-1996-799 [sk. 26.09.2016.]. 